International Review of Research in Open and Distributed Learning Volume 21, Number 4

November - 2020

\title{
E-Learning Challenges in Iran: A Research Synthesis
}

Hamed Abbasi Kasani ${ }^{1}$, Gholamreza Shams Mourkani2 ${ }^{2}$, Farhad Seraji ${ }^{3}$, Morteza Rezaeizadeh ${ }^{4}$, and Hojjat Abedi ${ }^{5}$

1,2,4,5 Shahid Beheshti University, Iran, ${ }^{3}$ Bu Ali Sina University, Iran

\begin{abstract}
This study investigates and fully identifies the challenges of the Iranian e-learning system. The approach was qualitative and the method was research synthesis. The statistical population consisted of studies from 2006 to 2019 in the field of challenges of the e-learning system of Iran collected with specific keywords from the country's databases. A total of 48 studies were identified as relevant. They were screened in stages and evaluated based on their title, abstract, and content. The final 19 articles selected underwent content analysis, revealing that Iran's e-learning system faces problems in eight dimensions: legal, human, educational, technological, sociocultural, support, economic, and managerial-organizational. The results of the analysis could serve as a model for countries with similar technology infrastructure and cultural features wishing to improve their e-learning systems.
\end{abstract}

Keywords: e-learning, challenge, Iran, research synthesis, model 


\section{Introduction}

Higher education in Iran started in the middle of the 19th century and is now part of the education system, under the supervision of the Ministry of Science, Research and Technology, the Ministry of Health and Medical Education (University of Medical Sciences), and the Ministry of Education (University of Farhangian). Iranian higher education leads to degrees of associate, bachelor's, master's, and doctorate. Studies into Iranian higher education indicate that the current bureaucratic and centralized system is not capable of directing higher education centers and this has reduced the quality of education and learning.

Enhancing learning and teaching at universities has always been an important issue (Muyinda, 2007). To this end, using technology to support teaching and learning can be effective. Technology is constantly modernizing education and is now an integral part of the learning environment. Undoubtedly, the Web and all its domains have provided unprecedented opportunities and platforms for learning. One of the emerging opportunities that has changed traditional formal education in terms of quality, quantity, accessibility, cost, and delivery is e-learning (Aljamal, Cader, Chiemeke, \& Speece, 2015; Liu, 2013). E-learning provides a new generation of learning that can assist institutions to achieve manifold goals (Taha, 2014) and play a key role in the learning process (Kc, 2017).

The word e-learning has been used since the third millennium $\mathrm{AD}$ and its meaning is still expanding. Today, the term mainly refers to the use of online technologies to enhance the teaching-learning process and the acquisition of knowledge and skills (Ostad et al., 2019; Uppal, Ali, \& Gulliver, 2018). E-learning means using information and communication technology to enhance and support learning at every level of education (Cidral, Oliveira, Di Felice, \& Aparicio, 2018; Dev, 2018). In fact, e-learning uses technology to facilitate the learning process, making it independent of time and place. What is more, the learner is much more active in this type of learning than in traditional methods.

Since information is central in the present era, e-learning is considered a necessity for an informationdriven society. Similarly, universities cannot ignore e-learning thanks to the development of computers and the Internet in education. Proper application of an e-learning system in universities can help develop skills to use online academic content, in addition to introducing teachers and students to new teaching methods (Shahnavazi, Mehraeen, Bagheri, Miri, \& Mohammadghasemi, 2017). Studies also show that e-learning, as a learner-centered teaching method, facilitates and improves higher-order cognitive skills such as analysis, synthesis, evaluation and judgment, critical thinking, and problem solving (Zarei, Javaheri, \& Shikhi, 2019). In general, the goal of e-learning is to eliminate time, place, and educational resource constraints, to provide equal, free, and searchable access to courses, to create a uniform learning environment for different groups of individuals in any location, and to optimize delivery of lesson content for deeper and newer learning (Uppal, Ali, \& Gulliver, 2018; Zare \& Saeed, 2017).

E-learning officially started in Iran in mid-2002. Subsequently, many e-learning courses were launched in 2004 by Shiraz University, granting a degree in control and precise instrumentation engineering, followed by the University of Science and Technology, Khajeh Nasiruddin Tusi University, and Amir Kabir University which began to offer similar courses. The University of Payame Noor also started to develop curricula for semi-formal education in five disciplines at twenty-eight centers (Dosti, Madanipour, \& Bideglo, 2018). Given the growing number of students, the shortage of educational venues, the fact that many students have 
jobs (Rafiei, Ghaffari, \& Khorami, 2017), and the role of e-learning in the realization of the 5th Plan and Development Outlook of 1404 (knowledge-based development) (Zare \& Saeed, 2017), e-learning could be considered the most important educational method, especially in Iranian higher education. E-learning was developed in Iran by 2010 using the policies, rules, and regulations related to face-to-face education, and since then, efforts have continued. However, since e-learning is a strategic program, the problems and issues it faces should be identified and serious action taken to solve them. Therefore, this study, taking a qualitative approach, aimed to evaluate research conducted into e-learning challenges and was guided by the following question: what are the challenges in Iran's e-learning system?

\section{Method}

This qualitative study used a research synthesis method. The aim of research synthesis is to combine empirical research to make generalizations (Hedges \& Cooper, 2009). As shown in Figure 1, a seven-step method (Sandelowski \& Barroso, 2006) was used to identify relevant studies for analysis.

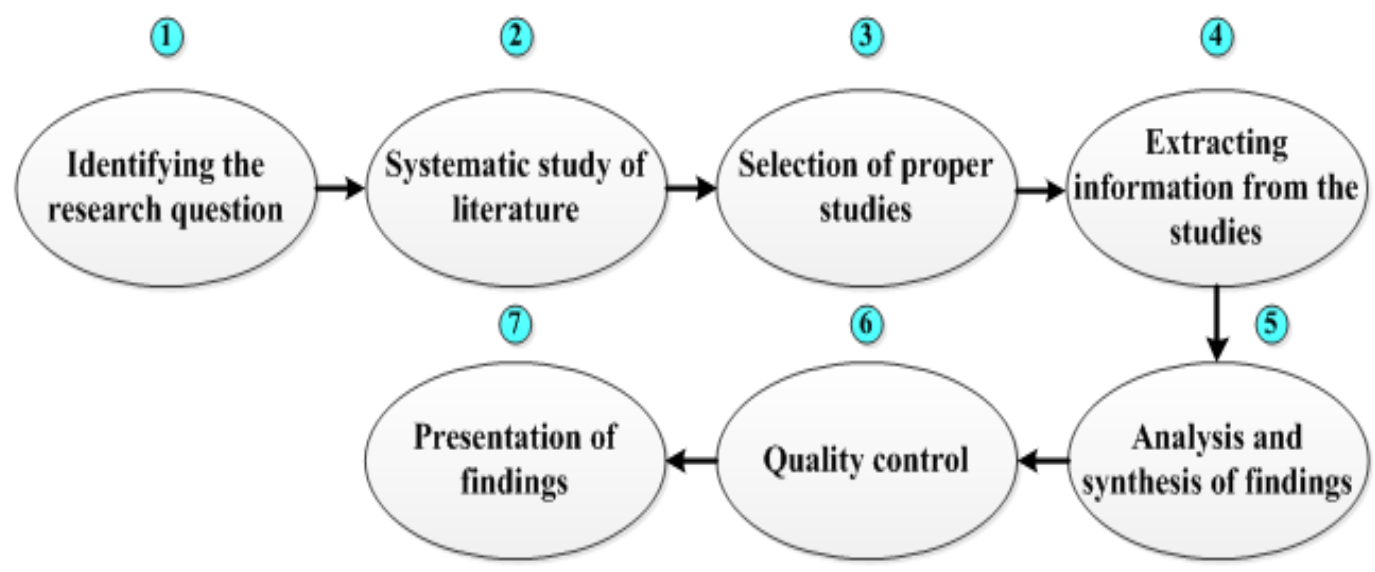

Figure 1. Research synthesis steps. Adapted from Handbook for synthesizing qualitative research, by M. Sandelowski and J. Barroso, 2006, Springer Publishing Company.

\section{Step 1: Identifying the Research Question}

In the first step, the main research question should be identified. We articulated our question as follows: what are the challenges in Iran's e-learning system?

\section{Steps 2 and 3: Systematic Study of Literature and Selection of Relevant Studies}

The statistical population of this research includes studies from 2006 to 2019 in the field of e-learning challenges. The largest Iranian databases, including CIVILICA, Magiran, Ganj, Noormags, and SID, were searched using these keywords:

- e-learning / distance learning pathology;

- $\quad$ e-learning / virtual education pathology;

- electronic learning / distance learning challenges; 
- electronic learning / virtual learning challenges;

- e-learning / distance learning barriers;

- e-learning / virtual learning barriers;

- e-learning / distance learning threats; and

- e-learning / virtual learning threats.

As shown in Figure 2, 48 studies were selected from the databases and evaluated. From among these, 19 were finally selected for analysis after several screening stages based on title, abstract, and content.

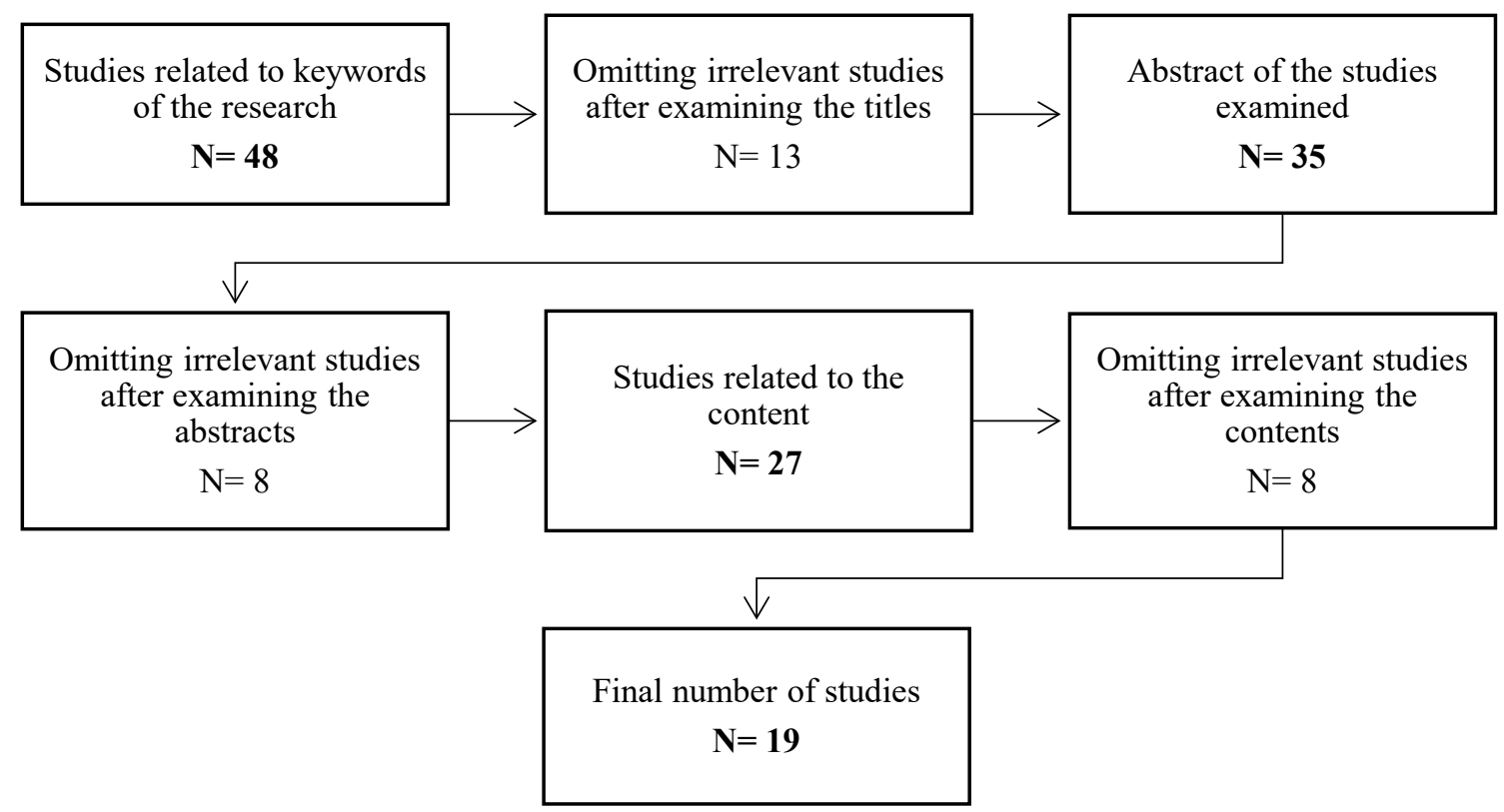

Figure 2. Stages of selecting, refining, and organizing research. Figures in bold are the number of studies remaining after completion of each step, showing how the total number of studies was reduced.

In this screening, the critical appraisal skills program (CASP) proved useful for evaluating quality. CASP offers 10 questions to determine the accuracy, validity, and importance of research studies. According to Mohamadian, Manian, and Khodadad Beromy (2015), these questions focus on: (a) research objectives; (b) methodology logic; (c) research design; (d) sampling method; (e) data collection; (f) reflectivity; (g) ethical considerations; (h) accuracy of data analysis; (i) clear expression of findings; and (j) research value. Members of the research team examined and evaluated the articles using CASP and selected those which received a good (31-40) or excellent (41-50) score on the 50-point scale.

The 19 selected studies are shown in Table 1. 
Table 1

Post-Screening Studies Selected for Coding

\begin{tabular}{|c|c|c|}
\hline $\begin{array}{l}\text { Article } \\
\text { code }\end{array}$ & Source & Year \\
\hline 1 & Zarei, Javaheri, \& Shikhi & 2019 \\
\hline 2 & Ghasemi, Fardanesh, Hatami, \& Ahmady & 2018 \\
\hline 3 & Dosti, Madanipour, \& Bideglo & 2018 \\
\hline 4 & Vardasbi, RezaeiZadeh, Khorasani, \& Alikhani & 2018 \\
\hline 5 & Abbasi Kasani, Haji Zeynalgabedini, \& Raisi & 2018 \\
\hline 6 & Tari, Shams, \& Rezaeizadeh & 2017 \\
\hline 7 & Mohsenzadeh & 2017 \\
\hline 8 & Mahmoudi \& Purnasir & 2017 \\
\hline 9 & Mahmoudi \& Hashemikia & 2017 \\
\hline 10 & Naderifar, Ghaljaie, Jalalodini, Rezaie, \& Salalr & 2016 \\
\hline 11 & Paykani & 2016 \\
\hline 12 & Ghahramani & 2015 \\
\hline 13 & Bagherimajd, Shahei, \& Mehralizadeh & 2013 \\
\hline 14 & Asghari et al. & 2012 \\
\hline 15 & $\begin{array}{l}\text { Khatib Zanjani, Zandi, Farajollahi, Sarmadi, \& } \\
\text { Ebrahim Zadeh }\end{array}$ & 2012 \\
\hline 16 & Arabsorkhi \& Yadegari & 2011 \\
\hline 17 & Majidi & 2009 \\
\hline 18 & Etezadi, Arefi, \& Aghakasiri & 2009 \\
\hline 19 & Rahimi Doost & 2007 \\
\hline
\end{tabular}

\section{Steps 4 and 5: Extracting Information From Research and Analyzing and Synthesizing Findings}

Conducting a study using the research synthesis method requires qualitative analysis of previous studies and findings in a specific field. One of the most effective methods of undertaking such a process is content analysis using coding that leads to the discovery of a framework of patterns (Hsieh \& Shannon, 2005). Coding can be used when the researcher wishes to analyze the data obtained from events. Corbin and Strauss (2008) proposed three coding techniques: open, axial, and selective coding. Open coding is an analytical process through which concepts are identified and their features and dimensions discovered in the data. Axial coding is the process of linking categories to subcategories and connecting categories at the level of attributes and dimensions. Selective coding is also a process of integration and improvement of categories (Lee, 2001). MAXQDA 10, a software program used for analyzing qualitative data, together with 
the three-step encoding method of Corbin and Strauss were used for data analysis. Content related to the research question was first identified in the selected studies and, after repeated reviews, the initial open codes were extracted. Then, to create links between open codes, similar codes that had the same connotation were classified as axial codes. In the last step, the data were selectively coded and axial codes with the same connotation were placed in one category or dimension.

\section{Step 6: Quality Control}

In order to maintain quality in this study, research papers were evaluated based on indices such as objectivity, methodology logic, research design, ethical considerations, clear expression of findings, and research value, and only papers that scored high were selected for the next steps in the process. Furthermore, to ensure the coding was reliable, the intra-thematic agreement between two coders method was applied. An expert researcher re-encoded the data. To determine the reliability value, the Kappa Cohen coefficient formula was used. More specifically, three interviews were re-coded by the other coder and then the inter-coder agreement was calculated, resulting in a reliability of 0.73 .

\section{Step 7: Presentation of Findings}

At this step, the results of the previous steps are presented.

\section{Findings}

Table 2 summarizes the results of the analysis of studies. Open source codes were juxtaposed, resulting in a number of categories. To determine each axial code, the open codes extracted in the first step were examined and those that resembled each other were grouped under the axial code that represented their meaning, i.e., factor. Afterward, homogeneous axial codes were categorized to form dimensions (selective codes).

Table 2

Classification of Thematic Categories Derived From Coding and Their Source Articles

\begin{tabular}{clc}
\hline \multicolumn{1}{c}{ Factor } & \multicolumn{1}{c}{ Categories } & Article code \\
\hline \multirow{2}{*}{ Legalization } & \multicolumn{1}{c}{$\begin{array}{c}\text { Legal Dimension } \\
\text { Lack of emphasis and obligation regarding the use of educational } \\
\text { technology by higher education laws and regulations } \\
\text { Lack of necessary rules and regulations }\end{array}$} & 13,17 \\
& Lack of rubrics and weaknesses in making laws and regulations & $5,8,17$ \\
& & 6,17 \\
Instructor & Human Dimension & 2 \\
& Insufficiency and lack of timely presentation of class assignments & 5 \\
& Fear of inability to acquire necessary job skills & 2
\end{tabular}


Low instructor engagement and lack of essential guidance $\quad 2$

Inability of some instructors to work with the system 2

Poor eloquence of some instructors 2

Professors' reluctance to teach on time $\quad 5$

Professors' resistance to using technology in classrooms $10,14,17$

Some professors' concern about their role becoming diminished 10

Professors' lack of technological skills $\quad 11$

$\begin{array}{ll}\text { Professors' negative attitude toward e-learning } & 14\end{array}$

$\begin{array}{ll}\text { Professors' lack of motivation to adopt e-learning } & 14\end{array}$

$\begin{array}{ll}\text { Professors' insufficient time } & 14\end{array}$

Learner $\quad$ Students' reluctance to use this type of education $\quad 5$

Anxiety to face the computer and use it in students 5

Low level of motivation to interact 2

Heterogeneous students in terms of computer literacy and knowledge 5

Low level of information and computer literacy $\quad 2,5,9$

$\begin{array}{lr}\text { Large number of learners } & 2,5\end{array}$

Learners' lack of technological skills $\quad 11,13,19$

Learners' mental distraction and inattention to academic matters 12

$\begin{array}{ll}\text { Learners' reluctance to strive } & 2,11\end{array}$

Weakness in time management skills $\quad 1,19$

Low level of motivation to use e-learning by learners $\quad 13,19$

$\begin{array}{ll}\text { Lack of individual study skills } & 1,19\end{array}$

$\begin{array}{lr}\text { Low English proficiency of learners } & 8,13\end{array}$

Staff

Staff's lack of motivation $\quad 6$

$\begin{array}{lr}\text { Insufficient skilled workforce } & 2,5\end{array}$

\section{Educational Dimension}

Educational $\quad$ Lack of educational needs analysis $\quad 2$

$\begin{array}{lll}\text { needs analysis } \quad \text { Unrealistic needs analysis } & 6\end{array}$

Educational Lack of teacher training in e-learning $\quad 5$

designing and Weak access to content of discussions 4

$\begin{array}{lll}\text { planning } \quad \text { Failure to define e-learning goals } & 1,5\end{array}$

Failure to anticipate appropriate in-service courses to familiarize
teachers with teaching methods and process of using e-learning

Lack of established educational models 3

Inappropriate intensivity of content 2 
$\begin{array}{lr}\text { Repetitive and out-of-date content } & 2\end{array}$

Impractical content $\quad 2$

$\begin{array}{ll}\text { Inappropriate educational calendar } & 2\end{array}$

Failure to change educational processes $\quad 3$

$\begin{array}{ll}\text { Mismatch between existing curricula and ICTs } & 1\end{array}$

$\begin{array}{ll}\text { Difficulty creating content for e-learning practices } & 8\end{array}$

Inattention to the learner and their needs in setting goals $\quad 11$

$\begin{array}{ll}\text { Inappropriate and insufficient content } & 6,17\end{array}$

$\begin{array}{lr}\text { Poor curriculum design } & 19\end{array}$

$\begin{array}{ll}\text { Poor e-class design } & 19\end{array}$

$\begin{array}{ll}\text { Poor quality of e-learning based educational packages } & 14\end{array}$

Execution Decrease in face-to-face and non-verbal communication $\quad 5,12$

$\begin{array}{lr}\text { Improper implementation of e-learning } & 6\end{array}$

$\begin{array}{ll}\text { Inappropriate timing of some e-classes } & 7\end{array}$

Using old techniques and methods $\quad 5$

$\begin{array}{lr}\text { Restrictions on practical and skill-based courses } & 6,12\end{array}$

Emphasis on teacher-centered methods $\quad 12$

Users being accustomed to traditional education systems 13

Inefficient education $\quad 1,16$

$\begin{array}{lr}\text { Poor supervision of educational processes } & 16\end{array}$

Evaluation $\quad$ Lack of specific standards for evaluating educational programs $\quad 5$

Uncertainty about validity of educational evaluations 5

Low test duration $\quad 2$

In-person evaluation $\quad 2$

Lack of procedures for designing evaluations appropriate for e-learning 5

Impossibility of evaluating all aspects of learning 11

Technological Dimension

$\begin{array}{llr}\text { Software } & \text { Weaknesses in supporting software systems } & 10,11,18\end{array}$

Weakness in software resources $\quad 5,12,14,17$,

18,19

Incompatibility of some software programs with personal computers $\quad 7,18$

$\begin{array}{ll}\text { Inaccessibility of main software programs } & 8,18\end{array}$

Hardware Weakness in hardware resources $\quad 5,12,13,17$, 18,19 
Insufficient hardware

$7,8,11,13$,

14,15

Internet

Learning management system

Society's attitude

Resistance to change

Cultural and social values

Low Internet speed

Lack of proper communication platforms

Internet disconnection

Expensive network communication platforms

Low bandwidth

Lack of familiarity with Web design and systems

5,16

Unattractive system appearance and poor UI

Inability of some instructors to work with the system

Complexity of system

Learners' lack of access to their performance evaluations

Sociocultural Dimension

Low value of a university degree in the minds of entrepreneurs and the public

Disbelief in virtual education

Improper status of e-learning

Objectification of learners

Fear of presence of new technology

Resistance to adoption of e-learning

6,17

Lack of culture conducive to adoption of e-learning

1,14
Lack of copyright in the software community of the country

5

Resistance due to traditional, cultural values

1,10

\section{Support Dimension}

Conditions and Inadequate quality of equipment

facilities

Weakness in online support

$1,5,11$

2

Scientific

Shortage of native scientific resources in the field of e-learning

sources

\section{Economic Dimension}

Investment
$5,8,18$ 
$5,13,18$

financial

Low financial resources

2,17

resources

Cost

High cost of e-learning

$5,13,17,18$

High initial costs

5,8

Cost of keeping technology up-to-date

Hardware and software costs of e-learning

\section{Managerial-Organizational Dimension}

Organizational Failure to precisely define organizational structures for implementing structure e-learning

Management Lack of experienced managers to manage the e-learning system

Lack of specific mechanisms in the Ministry of Sciences' policy-making and planning units

Establishment of e-learning system
Rejection of e-learning in some universities

Insufficient dissemination of e-learning capacities

Uncertainty about efficiency of virtual universities

Multiple decision making centers

Multiple administration centers

Higher education authorities' reluctance to establish a virtual university
10,17

6,16

13

8

8

13

5,17

Misconception that e-learning is inefficient and resistance to it

17 attitude to e- $\quad$ Fear of failure learning

Note . Dimension $=$ selective coding; Factor $=$ axial coding; Categories $=$ open coding; ICT $=$ Information and Communications Technology; UI = user interface. Article codes are assigned in Table 1. 


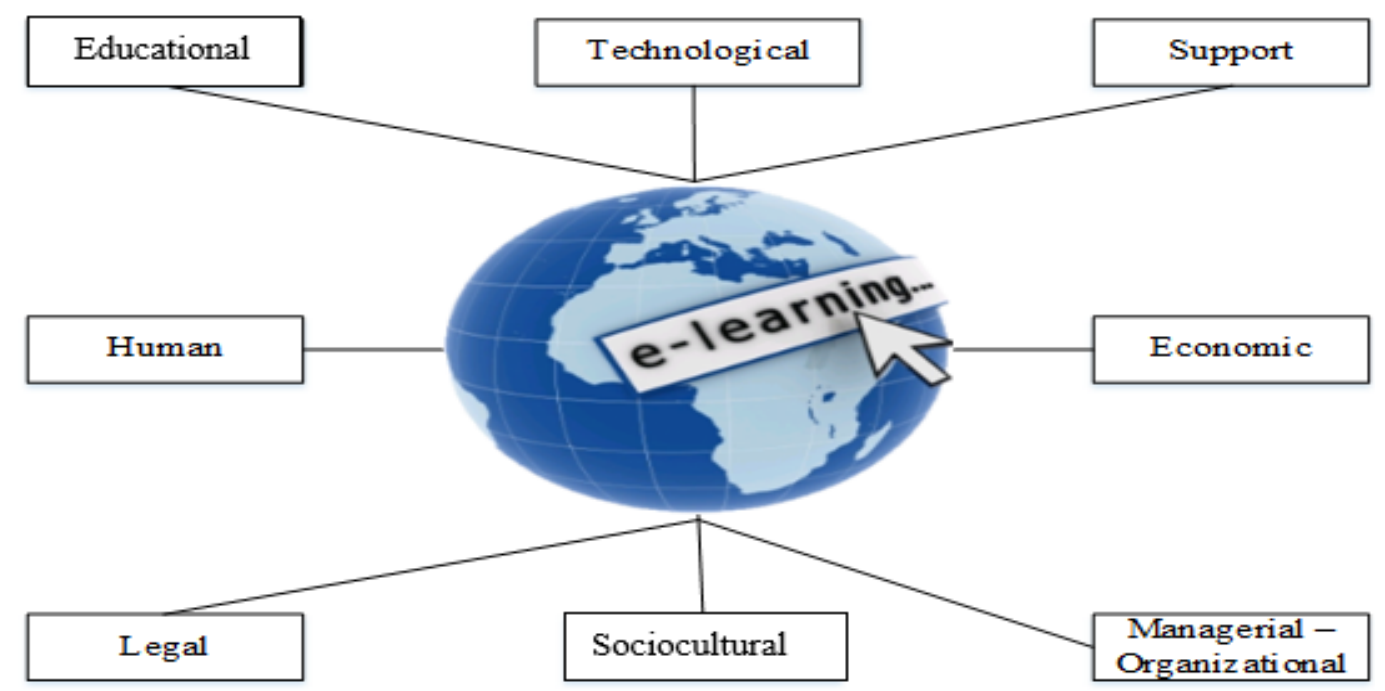

Figure 3. Challenges of the Iranian e-learning system.

These eight dimensions of setbacks and problems are discussed next.

\section{Discussion}

Legal dimension. The findings indicated that Iran's e-learning system has a major legal issue which is related to e-learning system regulation. When implementing e-learning, communities and organizations are required by law to provide rubrics on certain issues related to instructors, learners, managers, and support services in order to identify a framework of activities and ensure compliance with the education system (Bashiruddin, Basit, \& Naeem, 2010). However, Iran has so far failed to properly implement and enforce its e-learning laws and regulations (Abbasi Kasani, Haji Zeynalgabedini, \& Raisi, 2018) and this has caused the e-learning system to break down. Creating incentives and educational requirements for the delivery of learning content and educational interactions through cyberspace and in academic e-learning settings can greatly reduce resistance to e-learning.

Human dimension. This dimension pertains to the human factors related to the teacher, learner, and e-learning system personnel.

The teacher plays a key role in transferring knowledge, skills, and sense of competition, as well as in determining student satisfaction (Paechter, Maier, \& Macher, 2010). The e-learning teacher acts as a facilitator who identifies educational goals, quality learning resources, learning activities, and evaluation practices (Khorasani, A'lami, \& Razavizadeh, 2017). Teachers are also required to have computer skills as these are at the foundation of activities in such a system. Teachers sometimes resist adopting e-learning because they feel their current status may be endangered. However, they should be familiarized with the advantages and necessity of e-learning in the present age through courses and workshops to help minimize this resistance. Additionally, a teacher's eloquence is one of the features of creative teaching from a learner's perspective. Learners believe that a teacher should be able to convey content effortlessly. A teacher's online presence is also important. Without it, learning can suffer due to the lack of thorough analysis and review 
by the professor and the failure to initiate student participation when discussing lesson components. Misinterpretation leads to a student's confusion and loss of motivation (Mohsenzadeh, 2017).

The learner is one of the key players in the teaching-learning process. The learner-centered approach in the e-learning system actively engages learners so they can experience more effective learning by interacting with the environment, content, teacher, and other students (Khorasani et al., 2017). Motivation also influences the perceptions and concentration of the learner. With motivation, access to information, even when scarce, becomes possible. Furthermore, learners' participation in e-learning increases their motivation for further effort and persistence (Shangeerthana \& Chandrasekar, 2016; Taha, 2014). Access to computers and the Internet or Intranet is essential and requires some knowledge of computer use and troubleshooting. Gaining such knowledge, however, can be costly and time-consuming (Tarin, 2016). Information literacy is another factor related to the learner. Information literacy is a set of skills enabling one to recognize their information needs, formulate search methods by identifying available information sources, evaluate the information obtained after conducting the search, and make necessary connections between new information and previous knowledge in order to generate new information (Gholami \& Gavgani, 2011). Unfortunately, there are some setbacks in the area of information literacy in the Iranian elearning system.

One of the important factors related to the learner which determines the success of e-learning is computer skills (Mosakhani \& Jamporazmey, 2010; Taha, 2014). Learners need computer skills to be able to participate in e-learning. Poor computer skills can cause anxiety and result in learners being unable to take advantage of the benefits of e-learning (Selim, 2007). The characteristics of learners and their attitudes toward e-learning can also influence their success. The more compatible learners are with e-learning, the more likely they are to have a positive attitude toward it and be engaged in it, and thus succeed and improve their e-learning experience.

The research revealed certain issues with staff as another human factor influencing the Iranian e-learning system. Some staff lack motivation and there is a shortage of skills in the workforce. In principle, motivation is the momentum for an individual to pursue an activity to achieve success, and its absence will consequently cause problems (Tari, Shams, \& Rezaeizadeh, 2017). Managers should encourage employees to use e-learning to provide better quality services, and to have a high level of motivation and positive attitude toward this mode of learning. Furthermore, to address the need for a skilled workforce, managers should make an effort to use e-learning to educate experts in each field (Bagherimajd, Shahei, \& Mehralizadeh, 2013). E-learning is one of the most important issues in organizations and can be a factor in solving problems related to learning and staff performance.

Educational dimension. The educational dimension refers to factors influencing all steps in the education process including needs analysis, planning and design, implementation, and evaluation. Currently, the underlying problem in the e-learning system is the almost total absence of proper educational principles. As a consequence, designers and trainers often apply principles better suited to traditional education systems. This in turn leads to forms of e-learning that are nothing more than flipping through web pages and filling in e-mail boxes or providing simple alternatives to classroom-based learning (Dosti et al., 2018). In fact, one of the fundamental issues is lack of quality in the needs analysis, design, development, and delivery of e-learning, which, when addressed, will solve the problems of this type of 
learning (Ghasemi, Fardanesh, Hatami, \& Ahmady, 2018). Educational design in network-based learning also has a significant impact on variables such as motivation for academic achievement (Noesgaard \& Ørngreen, 2015). Furthermore, one of the essential requirements is the production of e-content (Tari et al., 2017). Mazini (2009) considers content as the most important challenge and obstacle to the development of e-learning in Iran. In fact, content in Iran's e-learning system is dated and lacking coherence.

Technological dimension. The technological dimension includes hardware, software, the Internet, and e-learning system infrastructures. To be successful, e-learning needs to be reinforced in terms of hardware and software, and new technologies and related infrastructures must be employed. (Elkaseh, 2015; Shangeerthana \& Chandrasekar, 2016). Another factor that has dramatically changed education and learning is the Internet, which is, in principle, at the foundation of e-learning (Romi, 2017). In a similar vein, a number of researchers have pointed to e-learning issues caused by the lack of suitable hardware and software facilities, cost of access to the Internet, bandwidth limitations, and slow Internet speed (Gulati, 2008). E-learning, based on computer communication platforms, is dependent upon these platforms, and therefore, the absence or weakness of each component affects efficiency. Low bandwidth and slow Internet speed make users reluctant to try Web-based learning (Tari et al., 2017). Iran's e-learning system has not yet advanced far enough to be able to provide the necessary software and hardware infrastructures and thus has weaknesses in this respect.

Learner activities also take place in a learning management system (LMS). This system should cover all activities and provide a good user interface (UI). As the number of Internet users has soared in recent years, close attention has been paid to UI when creating Web applications. UI is defined as the interaction between people and a Web application (Abbasi Kasani \& Shams, 2018). In addition, learners expect to have access to some of the capabilities of the LMS. They also believe the results of their activity evaluations should be accessed through the LMS (Vardasbi, RezaeiZadeh, Khorasani, \& Alikhani, 2018).

Sociocultural dimension. The sociocultural dimension refers to conditions related to culture and society that influence the application and use of technology in education (Paykani, 2016). In light of the expanded use of e-learning, it is essential to promote it first and foremost in the academic community and then in the community in general. By raising awareness about the features, goals, and benefits of elearning, community members can develop a more positive attitude toward e-learning, supporting users who will become more eager and active in this environment (Ghasemi et al., 2018). Right now, there is a stigma attached to e-learning and people in the community generally do not value virtual education. They deem e-learners as individuals who are only in pursuit of a degree, not of learning. What is paramount in using technology is defining the path, speed, direction, and ultimate purpose (Tarin, 2016). Should these goals be well defined and made transparent to members of the community, it can be argued that resistance to e-learning will diminish.

Support dimension. The support dimension is concerned with online support and resources needed to foster meaningful learning environments (Abbasi Kasani et al, 2018). The research findings suggested that there are deficiencies in terms of facilities and scientific resources in the Iranian e-learning system. Within any organization involved in e-learning, it is essential that clear reasons for distance learning are provided, the extent of responsibility and independence of the learner and teacher are determined, and personal and educational support are provided. E-learning courses should also be 
supported in terms of scientific, technical, and guidance resources. However, in the e-learning system in Iran, there is a shortage of technological, economic, and even cultural infrastructure which has resulted in Iran suffering from lower quality equipment when compared to many other countries, impinging on online support as well. Another aspect of support pertains to native scientific resources. Native scientific resources are currently scarce and instead more foreign scientific resources are being used. While the experience and knowledge of other countries are important, national scientific development is also a necessity.

Economic dimension. The economic dimension includes all matters related to investment, budget and finance, and cost. Despite the growing importance of e-learning, there is still less investment in this sector when compared to traditional education, and there is no significant separate funding available for it. In addition, the cost structure in e-learning is quite different from that in conventional education. Large-scale e-learning programs may train more graduates at a lower cost than conventional systems. The costs depend on the use of learning materials, media, technologies, and the organization that provides support to learners (Tarin, 2016). On the other hand, establishing an e-learning approach necessitates provision and maintenance of various infrastructures and therefore costs a lot initially (Mahmoudi \& Hashemikia, 2017), which in turn makes decision makers reluctant to commit to e-learning.

Managerial-Organizational dimension. The organizational dimension refers to structural and administrative factors within a body. The research findings indicated that the managerialorganizational dimension of Iran's e-learning system has been adversely affected by factors such as organizational structure, management and leadership, planning and policy making, e-learning system establishment, and managers' attitudes toward e-learning. It is important to obtain the approval of highlevel managers, who need to understand how e-learning can reduce costs, improve product quality and profitability, and enhance employee performance as well as customer satisfaction (Bagherimajd et al, 2013). Managers can be a determining factor in improving and streamlining change in their organizations. When an organization wants to improve the workflow of a process, it requires formulation of an executive approach. Just as the articulation of policies and procedures for e-learning is considered essential, the lack of planning and educational strategies and support specific to e-learning can make adopting this approach challenging (Tari et al., 2017). Hadadyan (2011) demonstrated that organizations do not provide conditions conducive to e-learning, which is in line with the results of the present study.

Another major pathology of the e-learning system lies in its establishment and implementation. Currently in Iran, six governmental bodies consider themselves to be in charge of e-learning: the Ministry of Science, Research and Technology; the Ministry of Education; High Council of Information; the Ministry of Information and Communications Technology; the Islamic Republic of Iran Broadcasting; and the Management and Planning Organization. As a consequence, each adopts different policies, approaches, and guidelines, and they also use different methods of conducting e-learning courses (Mahmoudi \& Hashemikia, 2017). Such a multiplicity of agents leads to poor quality and even failure of the e-learning system. What is more, in some cases there is resistance to e-learning. This resistance usually emanates from an individual with extensive experience and belief in the real classroom, who resists change in organizational structure and questions the need to change in the first place, who may have a fear of technology and is reluctant to enter a new learning cycle, and, finally, has insufficient knowledge of elearning benefits (Aoki \& Pogroszewski, 1998). 


\section{Limitations}

In this study, a comprehensive identification of e-learning system challenges in Iran was investigated using only a synthesis method. However, the challenges of the Iranian e-learning system could also be addressed with the help of other data collection methods and tools such as interviews and questionnaires. Moreover, the views and opinions of professors, students, and stakeholders were not considered in this study. These limitations however suggest directions for future research.

\section{Conclusion}

Technology has a remarkable capability to modify or redefine teaching and learning activities in all institutions of higher education and provides opportunities to design scientific environments previously thought to be impossible. For this reason, many universities in Iran are keen to launch e-courses to capitalize on the merits of information technology in the form of e-learning. However, the e-learning system already launched in many universities in the country faces numerous challenges and problems. These include deficiencies in 8 areas: legal, human, educational, technological, sociocultural, support, economic, and managerial-organizational. Findings could prove beneficial for countries similar to Iran in terms of technology infrastructure and cultural features.

This study has eight recommendations to support e-learning in Iran. We suggest the adoption of these measures: (a) employment of technical experts in the field of virtual education to train teachers as well as learners and raise their awareness; (b) establishment of an e-learning culture through websites and the media; (c) justification of the values and benefits of e-learning; (d) creation of motivational and support mechanisms, such as providing facilities, enhancing knowledge and skills, and providing financial support for technology purchase and use; (e) provision of the infrastructure needed to implement e-learning effectively; (f) hiring of competent and caring managers in e-learning institutions; (g) development of laws and regulations related to the e-learning system; and (h) allocation of sufficient funding. 


\section{References}

Abbasi Kasani, H., \& Shams, Gh. R. (2018). A research synthesis of critical success factors of e-learning: A model development. Technology of Education, 13(1), 133-146. doi: 10.22061/jte.2018.3061.1777

Abbasi Kasani, H., Haji Zeynalgabedini, M., \& Raisi, A. (2018). Pathology of University of Medical Sciences e-learning system based on Khan model. The Journal of Medical Education and Development (JMED), 12(4), 227-238. Retrieved from http://jmed.ssu.ac.ir/article-1-825en.html

Aljamal, A., Cader, H., Chiemeke, C., \& Speece, M. (2015). Empirical assessment of e-learning on performance in principles of economics. International Review of Economics Education, 18, 3748. doi: 10.1016/j.iree.2015.02.002

Aoki, K., \& Pogroszewski, D. (1998). Virtual university reference model: A guide to delivering education and support services to the distance learner. Online Journal of Distance Learning Administration, 1(3), 1-15. Retrieved from https://www.westga.edu/ distance/ojdla/fall13/aoki13.html

Arabsorkhi, A., \& Yadegari, A. (2011). Identifying and analysis of security challenges and solutions in elearning environments. Iranian Journal of Information Processing and Management, 26(2), 441-464. Retrieved from https://jipm.irandoc.ac.ir/article-1-1360-en.html

Asghari, M., Alizadeh, M., Kazemi, A., Safari, H., Asghari, F., Bagheri-Asl, M. M., \& Heidarzadeh, S. (2012). An investigation of the challenges of e-learning in medical sciences from the faculty members' viewpoints of Tabriz University of Medical Sciences. The Journal of Medical Education and Development (JMED), 7(1), 26-34. Retrieved from http://jmed.ssu.ac.ir/article-1-68-en.html

Bagherimajd, R., Shahei, S., \& Mehralizadeh, Y. (2013). Assessing challenges in the development of electronic learning in higher education (Case study of Shahid Chamran University in Ahwaz). Journal of Medical Education Development, 6(12), 1-13. Retrieved from http://zums.ac.ir/edujournal/article-1-149-en.html

Bashiruddin, M., Basit, A., \& Naeem, M. (2010). Barriers to the implementation of e-learning system with focus on organizational culture (Master's thesis, Mälardalen University, Västerås and Eskilstuna, Sweden). Retrieved from http://urn.kb.se/resolve?urn=urn:nbn:se:mdh:diva-9923

Cidral, W. A., Oliveira, T., Di Felice, M., \& Aparicio, M. (2018). E-learning success determinants: Brazilian empirical study. Computers \& Education, 122, 273-290. doi: 10.1016/j.compedu.2017.12.001

Corbin, J., \& Strauss, A. (2008). Basics of qualitative research (3rd ed.). Thousand Oaks: Sage. doi: https://dx.doi.org/10.4135/9781452230153 
Dev, K. (2018). E-learning and higher education. International Journal of Academic Research and Development, 3(2), 1679-1682. Retrieved from http://www.academicjournal.in/archives/2018/vol3/issue2/3-2-240

Dosti, Z., Madanipour, M., \& Bideglo, F. (2018). Opportunities and threats of electronic learning and the solutions to counter the threats. Fourth National Conference and First International Conference on Transformation and Innovation in the Humanities, Shiraz, August 16. Retrieved from https://www.tpbin.com/article/72692\#content1

Elkaseh, A. (2015). An investigation of the factors for adopting e-learning in Libyan higher education for learning and teaching (Doctoral dissertation, Murdoch University, Perth, Australia). Retrieved from http://researchrepository.murdoch.edu.au/id/eprint/31008

Etezadi, M., Arefi, M., \& Aghakasiri, Z. (2009). Investigating the problems of the distance learning centers: The viewpoints of the teachers and the students of Isfahan's high schools in the academic year 2008-2009. Research in Curriculum Planning, 1(23), 149-177. Retrieved from http://isse.khuisf.ac.ir/article $534159 . h t m l$

Ghahramani, F. (2015). Explaining the philosophical approaches of e-learning and its pathology in Iranian higher education (to provide performance improvement strategies) (Master's thesis, Tarbiat Modares University, Tehran, Iran). Retrieved from https://parseh.modares.ac.ir/thesis/1056805

Ghasemi, M., Fardanesh, H., Hatami, J., \& Ahmady, S. (2018). Evaluation of the electronic learning system of medical education (Case study of Shahid Beheshti Medical School). Journal of Education Strategies in Medical Sciences, 11(4), 39-52. Retrieved from http://edcbmj.ir/article1-1618-en.html

Gholami, Z., \& Gavgani, V. Z. (2011). An overview on the concept of information literacy and its skills. Depiction of Health, 2(2), 34-39. Retrieved from https://doh.tbzmed.ac.ir/Article/doh-19

Gulati, S. (2008). Technology-enhanced learning in developing nations: A review. The International Review of Research in Open and Distributed Learning, 9(1), 1-16. doi: 10.19173/irrodl.vgi1.477

Hadadyan A. (2011). ارزيابى وضعيث آموزش الكترونيكى كشور در عصر جهانى شدن [Surveying national e-learning system in the globalization era]. Strategic Studies of Public Policy, 2(4), 117-148. Retrieved from http://sspp.iranjournals.ir/article 2473.html

Hedges, L.V., \& Cooper, H. (2009). Research synthesis as a scientific process. In H. Cooper, L.V. Hedges, \& J.C. Valentine (Eds.), The handbook of research synthesis and meta-analysis ( ${ }^{\text {nd }}$ ed.; pp. 316). Russell Sage Foundation Publications. Retrieved from https://b-ok.cc/book/2363591/39f1ee

Hsieh, H. F., \& Shannon, S. E. (2005). Three approaches to qualitative content analysis. Qualitative Health Research, 15(9), 1277-1288. doi: 10.1177/104932305276687 
Kc, D. (2017). Evaluation of Moodle features at Kajaani University of Applied Sciences-Case study. Procedia Computer Science, 116, 121-128. doi: 10.1016/j.procs.2017.10.021

Khatib Zanjani, N., Zandi, B., Farajollahi, M., Sarmadi, M. R., \& Ebrahim Zadeh, I. (2012). The structured analysis of requirements and challenges of e-learning and proposing a practical model for successful implementation of e-courses in medical sciences. Iranian Journal of Medical Education, 11(8), 995-1009. Retrieved from http://ijme.mui.ac.ir/article-1-1212-en.html

Khorasani, A., A'lami, F., \& Razavizadeh, S. (2017). Identifying the critical success factors in the academic e-learning centers (Qualitative study). Information and Communication Technology in Educational Sciences, 7(2), 26, 5-37. Retrieved from http://ictedu.iausari.ac.ir/article 656489 en.html

Lee, J. (2001). A grounded theory: Integration and internalization in ERP adoption and use. (Doctoral dissertation). Available from ProQuest Dissertations and Theses database. (UMI No. 3016318). Retrieved from https://search.proquest.com/docview/275713719

Liu, J. (2013). E-learning in English classroom: Investigating factors impacting on ESL (English as Second Language) college students' acceptance and use of the Modular Object-Oriented Dynamic Learning Environment (Moodle) (Master’s thesis). doi: 10.31274/etd-180810-3334

Mahmoudi, M., \& Hashemikia, A. (2017, June). Exploring the benefits, disadvantages, and challenges of e-learning. Paper presented at the Second National Congress on Transformation and Innovation in Humanities, Shiraz. Retrieved from https://www.civilica.com/Paper-ICCIHo2ICCIHO2 036.html

Mahmoudi, M., \& Purnasir, N. (2017, June). Challenges of learners and e-learning environments. Paper presented at the Second National Congress on Transformation and Innovation in Humanities, Shiraz. Retrieved from https://www.civilica.com/Paper-ICCIHo2-ICCIHo2 o68.html

Majidi, A. (2009). Electronic education: History, features, infrastructure, and obstacles. National Studies on Librarianship and Information Organization, 2O(2), 9-26. Retrieved from http://nastinfo.nlai.ir/article 262 en.html

Mazini, N. (2009). The challenges of learning in e-city. Research Institute for Information and Communication Technology, Proceedings of the Second International Conference on Electronic City, Tehran.

Mohamadian, A., Manian, A., \& Khodadad Beromy, M. (2015). A systematic review of research and future research directions of the virtual business incubators. BI Management Studies, 3(12), 123-150. Retrieved from http://ims.atu.ac.ir/article 1963 en.html

Mohsenzadeh, M. (2017). Pathology and solutions for promoting religious education in cyberspace. In Proceedings of the First International Conference on Capacity-Building and Impact of 
Cyberspace on Promoting Religious Education. Retrieved from https://www.civilica.com/PaperCICPRE01-CICPRE01_056.html

Mosakhani, M., \& Jamporazmey, M. (2010). Introduce critical success factors (CSFs) of e-learning for evaluating e-learning implementation success. In X. Zhou, D.S. Bhilare, \& A.N. Nambiar (Chairs), 2010 International Conference on Educational and Information Technology (ICEIT), Volume 1 (pp.224-228). doi: 10.1109/ICEIT.2010.5607745

Muyinda, P. B. (2007). M-learning pedagogical, technical and organisational hypes and realities. CampusWide Information Systems, 24(2), 97-104. Retrieved from https://www.learntechlib.org/p/101928/

Naderifar, M., Ghaljaie, F., Jalalodini, A., Rezaie, N., \& Salalr, A. (2016). Challenges of e-learning in medical sciences: A review article. Journal of Medical Education Development, 9(23), 102-111. Retrieved from http://zums.ac.ir/edujournal/article-1-707-en.html

Noesgaard, S. S., \& Ørngreen, R. (2015). The effectiveness of e-learning: An explorative and integrative review of the definitions, methodologies and factors that promote e-learning effectiveness. Electronic Journal of E-learning, 13(4), 278-290. Retrieved from https://www.learntechlib.org/p/160780/

Ostad, S. N., Ahmady, S., Mohammadi, A., Sabzevari, O., Mojtahedzadeh, R., Razavizadeh, M., \& Norouzadeh, A. N. (2019). Evolution of e-learning in Iran's medical sciences universities: Formation of Virtual University of Medical Sciences. Teb va tazkiye , 27(4), 233-243. Retrieved from http://www.tebvatazkiye.ir/article 83481 en.html

Paechter, M., Maier, B., \& Macher, D. (2010). Students' expectations of, and experiences in e-learning: Their relation to learning achievements and course satisfaction. Computers \& Education, 54(1), 222-229. doi: 10.1016/j.compedu.2009.08.005

Paykani, A. (2016). Pathology of e-learning curriculum in higher education (Master's thesis, Al-Zahra University, Tehran, Iran). Retrieved from https://ganj.irandoc.ac.ir/\#/articles/obgbcce555a49fb4feag91eb7d9o8bb3

Rafiei, M., Ghaffari, H., \& Khorami, M. (2017). Evaluating the effectiveness of e-learning method in human resource education (Case study of Markazi Province PNU). Research in School and Virtual Learning, 4(16), 71-84. Retrieved from http://etl.journals.pnu.ac.ir/article 3694.html

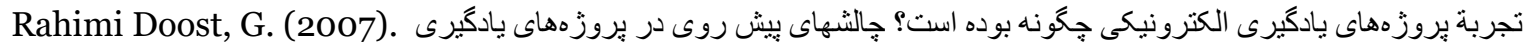
[How has the experience of e-learning projects been? Challenges facing e-learning projects]. Library and Information Sciences, 10(2), 337-355. Retrieved from http://lis.aqrlibjournal.ir/article 44100.html 
Romi, I. M. (2017). A model for e-learning systems success: Systems, determinants, and performance. International Journal of Emerging Technologies in Learning, 12(10), 4-20. doi: 10.3991/ijet.v12i10.6680

Sandelowski, M., \& Barroso, J. (2006). Handbook for synthesizing qualitative research. New York: Springer Publishing. Retrieved from https://books.google.com/books?hl=en\&lr=\&id=rjNMHog8fFsC\&oi=fnd\&pg=PR5\&dq=Sandelo wski, + M., $+\% 26+$ Barroso, + J.+(2006).+Handbook+for+synthesizing+qualitative+research.+New +\&ots=Iojp5Uhyc1\&sig=hW1iHZzzdar2XRxJbgej1U89tkQ\#v=onepage\&q=Sandelowski\%2C\%20 M.\%2C\%20\&f=false

Selim, H. M. (2007). Critical success factors for e-learning acceptance: Confirmatory factor models. Computers \& Education, 49(2), 396-413. doi: 10.1016/j.compedu.2005.09.004

Shahnavazi, A., Mehraeen, E., Bagheri, S., Miri, Z., \& Mohammadghasemi, M. (2017). Survey of students readiness to use of e-learning technology. Journal of Paramedical Sciences \& Rehabilitation, 6(3), 60-66. doi: 10.22038/jpsr.2017.13629.1283

Shangeerthana, G. V., \& Chandrasekar, K. (2016). Re-think on critical successful factors of e-learning implementation in India based corporates. International Journal of Advance Research, Ideas and Innovations in Technology, 2(6), 1-9. Retrieved from https://pdfs.semanticscholar.org/a284/0596a265960ac34a56d8857a0a3444234e5b.pdf

Taha, M. (2014). Investigating the success of e-learning in secondary schools: The case of the Kingdom of Bahrain (Doctoral dissertation, Brunel University, London). Retrieved from http://bura.brunel.ac.uk/handle/2438/9237

Tari, F., Shams, G., \& Rezaeizadeh, M. (2017). Identifying and modelling of challenges for implementing e-learning in the Iranian National Gas Company: An interpretive structural modeling (ISM) approach. Quarterly Journal of Training \& Development of Human Resources, 4(14), 1-27. Retrieved from http://istd.saminatech.ir/En-Article/13970114112831101456

Tarin, H. (2016). Investigating e-learning opportunities and threats at Razi University (Master's thesis, Razi University, Kermanshah, Iran). Retrieved from https://ganj.irandoc.ac.ir//viewer/c5a7723bffge1807b2do289d3d523ed8

Uppal, M. A., Ali, S., \& Gulliver, S. R. (2018). Factors determining e-learning service quality. British Journal of Educational Technology, 49(3), 412-426. doi: 10.1111/bjet.12552

Vardasbi, F., RezaeiZadeh, M., Khorasani, A., \& Alikhani, P. (2018). Reviewing and examining the effective factors impacting on the accessibility of Shahid Beheshti University's courseware. Technology of Education, 12(2), 197-209. doi: 10.22061/jte.2018.3030.1769 
Zare, H., \& Saeed, N. (2017). Electronic learning and cognitive psychology...Opportunities and challenges. Quarterly Journal of Research in School and Virtual Learning, 5, 95-107. Retrieved from http://ensani.ir/file/download/article/20171202144105-9940-120.pdf

Zarei, E., Javaheri, M., \& Shikhi, A. (2019). Identifying effective factors and obstacles using electronic learning to increase mental health of primary school students in Karaj (A qualitative study). Technology of Education, 13(3), 773-783. doi: 10.22061/JTE.2018.3595.1905

\section{Athabasca} University

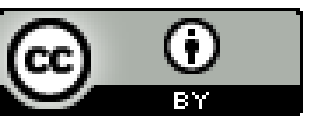

